\title{
Temporal and spatial patterns of zooplankton in the Chesapeake Bay turbidity maximum
}

\author{
M. R. Roman ${ }^{1, *}$, D. V. Holliday ${ }^{2}$, L. P. Sanford ${ }^{1}$ \\ ${ }^{1}$ Horn Point Laboratory, University of Maryland Center for Environmental Studies, PO Box 775, Cambridge, Maryland 21613, USA \\ ${ }^{2}$ BAE Systems, Suite 102, 4669 Murphy Canyon Road., San Diego, California 92123, USA
}

\begin{abstract}
We measured the distribution of hydrographic parameters, currents, phytoplankton fluorescence, suspended sediments and zooplankton in axial transects through the Chesapeake Bay estuarine turbidity maximum (ETM) seasonally (May, July and October 1996) and over tidal cycles within seasons. Zooplankton abundance was estimated with a 6-frequency, Tracor Acoustical Profiling System (TAPS-6) at the same vertical $(0.25$ to $0.50 \mathrm{~m})$ and horizontal $(0.5$ to $1.5 \mathrm{~km})$ resolution as hydrographic parameters and suspended sediments. The general pattern exhibited in axial transects through the Chesapeake Bay ETM is that sediments, fluorescence and zooplankton are in higher concentrations up-Bay of the salt wedge (defined as the intersection of the 1 isohaline with the bottom). The salinity front appears to trap these particles in the upper portion of Chesapeake Bay. The highest acoustically determined zooplankton biomass generally occurred near the bottom, at the toe of the salt wedge. The convergence zone associated with this feature concentrates sediments and zooplankton (primarily the copepod Eurytemora affinis). Advection appeared to dominate changes in zooplankton abundance during time series studies at a fixed station in the ETM. Zooplankton biomass at the fixed ETM station increased/decreased with the tidal excursion of the salt wedge. Water column zooplankton concentrations and the vertical distribution of zooplankton biomass appeared to be influenced by currents. We often found that during maximum ebb and flood tidal currents, zooplankton biomass and sediments in the mid and upper water column increased. Thus the hydrodynamic processes that resuspend, advect and trap suspended sediments in the ETM likely have the same effects on zooplankton. The ETM of the Chesapeake Bay appears to act as an entrapment zone for zooplankton. The lack of diel vertical migration, carrying eggs until they are ready to hatch, possible reduced predation by visual predators in the turbid waters, and the ability to consume phytoplankton, protozoa and detritus all may allow Eurytemora to persist at high concentrations in the Chesapeake Bay ETM.
\end{abstract}

KEY WORDS: Zooplankton · Estuarine turbidity maximum zone $\cdot$ Chesapeake Bay

Resale or republication not permitted without written consent of the publisher

\section{INTRODUCTION}

In most coastal plain estuaries, a zone of increased suspended particle concentration, the Estuarine Turbidity Maximum Zone (ETM), is associated with the landward limit of salt intrusion. The estuarine gravitational circulation results in a near bottom convergence at the salt limit, trapping settling particles which are resuspended by tidal currents (Schubel 1968, Biggs

*E-mail: roman@hpl.umces.edu
1970). The role of ETMs as entrapment zones supporting young fish production has been recognized in major estuaries, e.g. the St. Laurence River and San Francisco Bay (Dodson et al. 1989, Dauvin \& Dodson 1990). It is hypothesized that trophic transfers are enhanced in ETM regions and that reproductive success and recruitment of anadromous fishes are dependent upon linkages between estuarine physics and organism behavior.

The Chesapeake Bay ETM is variably located between $39^{\circ} 10^{\prime}$ and $39^{\circ} 28^{\prime} \mathrm{N}$ and typically extends 10 
to $30 \mathrm{~km}$ along the N/S axis of the bay (Fig. 1). The location of the ETM varies seasonally and at shorter time scales due to variations in freshwater input and wind-forcing. The ETM region of the Chesapeake Bay has a mean volume of approximately $2.63 \mathrm{~km}^{3}$ and a mean depth of $4 \mathrm{~m}$. Almost all of the freshwater input to the ETM region comes from the Susquehanna River. At the average Susquehanna River flow of $1100 \mathrm{~m}^{3} \mathrm{~s}^{-1}$, the freshwater replacement time of the ETM region is approximately $1 \mathrm{mo}$. Suspended sediment concentrations in the ETM are generally 40 to $80 \mathrm{mg} \mathrm{l}^{-1}$ higher than concentrations upstream or downstream of the ETM, with the largest concentrations resulting from tidal resuspension in near-bottom waters (Schubel 1968, Schubel \& Biggs 1969).

ETMs are frequently areas of enhanced zooplankton concentration. It is believed that abundant food, in the form of detritus, protozoa and phytoplankton, in addition to the convergence associated with estuarine circulation, results in high zooplankton concentrations. The calanoid copepod Eurytemora affinis often dominates the zooplankton found in ETM regions. In the ETM of the Chesapeake Bay Patuxent River Subestuary (Herman et al. 1968, Heinle \& Flemer 1975) E. affinis densities can reach $>1000$ nauplii $\mathrm{l}^{-1}$ and $>100$ adults $1^{-1}$. These values, as well as similar zooplankton concentrations reported for the ETM of the St. Lawrence estuary (Bousfield et al. 1975), Gironde estuary (Castel \& Veiga 1990), Columbia River estuary (Morgan et al. 1997), and San Francisco Bay estuary (Kimmerer et al. 1998), are among the highest re- corded abundances for copepods in marine waters. Eurytemora is an omnivore, ingesting phytoplankton (White \& Roman 1992), protozoa (Berk et al. 1977), bacteria (Boak \& Golder 1983) and detritus (Heinle et al. 1977). The ability to ingest suspended sediments and detritus with their associated microfauna allows Eurytemora to prosper on the high particle concentrations in the ETM. Egg production of Eurytemora within ETM regions apparently is not food limited (Heinle \& Flemer 1975, Peitsch 1995), suggesting that its high abundance and productivity within the ETM are consequences of a nutritionally favorable environment. Juvenile and adult stages of E. affinis are a dominant prey item of larvae of striped bass Morone saxatilis and white perch Morone americana in the Chesapeake Bay and other estuarine turbidity maximum systems (Setzler-Hamilton 1991, Setzler-Hamilton \& Hall 1991).

Eurytemora's behavioral and reproductive traits favor its retention in the ETM. Females carry their eggs in a sac where they develop until hatching. Egg-carrying Eurytemora usually reside in the bottom waters of the ETM (Heinle \& Flemer 1975, Morgan et al. 1997), a behavior that potentially reduces predation by visual predators as well as favoring retention in the ETM. Once hatched, peak abundances of Eurytemora nauplii are also associated with the bottom waters of the ETM region (Herman et al. 1968). In contrast, another calanoid copepod Acartia tonsa is a broadcast spawner, releasing eggs in surface waters which predisposes them to be advected out of the ETM region.
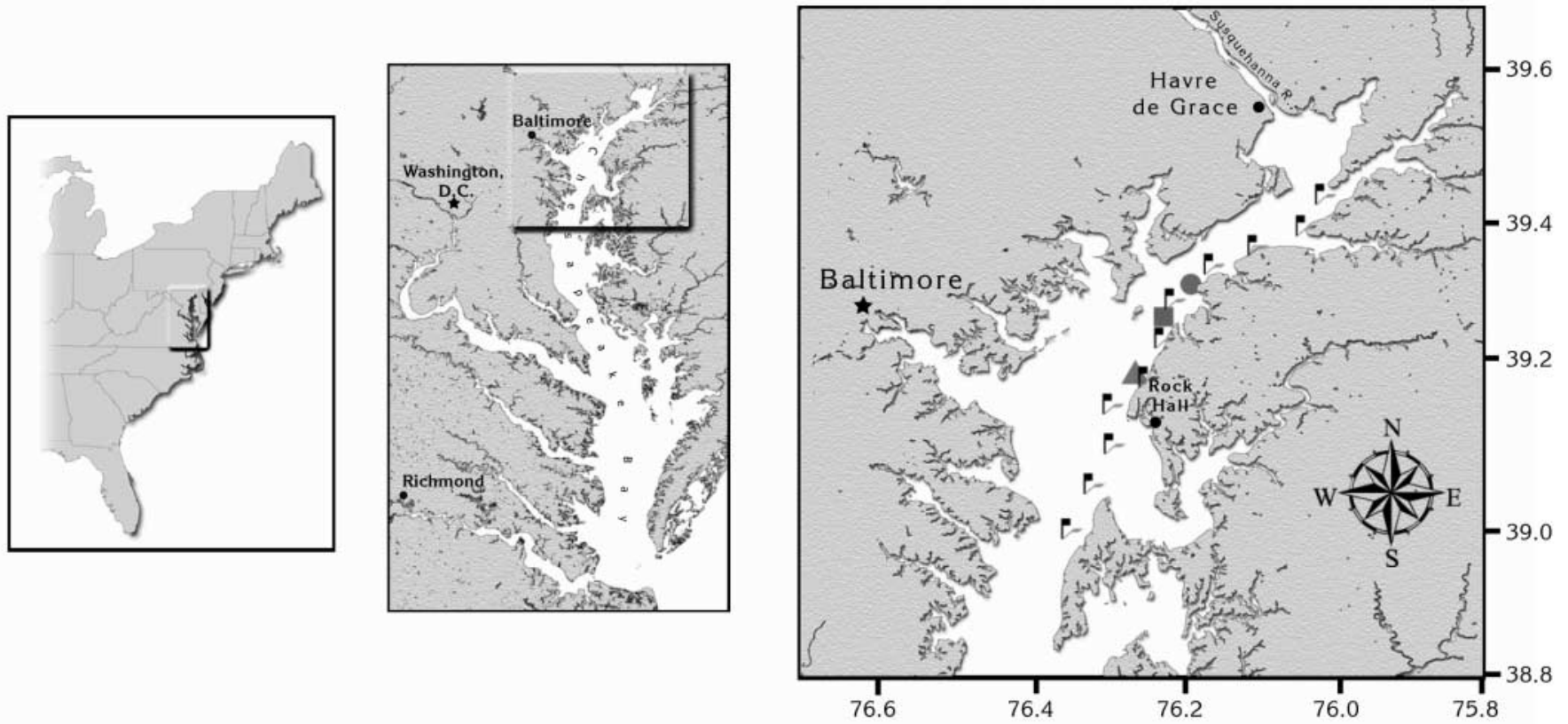

Fig. 1. US east coast, Chesapeake Bay and ETM study area in upper Chesapeake Bay. Standard stations (flags) in axial transect through ETM region; time series stations in ETM are represented by solid circle (May), square (October) and triangle (July) 
Vertical migration behavior of zooplankton in the Chesapeake Bay ETM and the role of behavior in maintaining populations within the ETM is poorly understood. Zooplankton may employ active and passive mechanisms to enhance retention in particular estuarine regions. For example, in the Conway Estuary (Hough \& Naylor 1991) and Columbia estuary (Morgan et al. 1997) scientists have suggested that Eurytemora vertically migrates in response to the tidal cycle to reduce being advected from the ETM region. The abundance of other copepod species (Morgan et al. 1997, Kimmerer et al. 1998) as well as Eurytemora in the Gironde estuary (Castel \& Veiga 1990) and in the Columbia estuary (Haertel \& Osterberg 1967) are highly correlated with temporal and spatial patterns of turbidity, suggesting that the same physical processes trap and concentrate sediments and zooplankton.

This research is part of the National Science Foundation Land Margin Ecosystem Research Program 'Trophic Interactions in Estuarine Systems' (TIES). The overall goal of the program is to examine the role of spatial and temporal physical structures in enhancing the coupling of phytoplankton, zooplankton and fish production in Chesapeake Bay. The ETM is one type of feature that may serve to enhance zooplankton production and the survival and recruitment success of fish. In this paper we describe the fine-scale distribution of zooplankton in relation to hydrographic parameters, phytoplankton fluorescence, suspended sediments and currents in axial sections through the Chesapeake Bay ETM, seasonally and over tidal cycles within seasons.

\section{METHODS}

During May, July and October 1996, we conducted research cruises in upper Chesapeake Bay (Fig. 1) on the ORV 'Cape Henlopen'. The sample days were selected to coincide with spring tides. Our sampling strategy included occupying stations along axial transects through the ETM and a fixed time-series (26 h) station located within the ETM. Vertical profiles with a Neil Brown CTD-rosette system provided measurements of temperature, salinity, oxygen, fluorescence and suspended sediment concentrations at a $0.25 \mathrm{~m}$ vertical resolution. Total suspended sediments (TSS) were estimated with a $5 \mathrm{~cm}$ path-length Sea Tech transmissometer using seston weights determined from whole water samples to convert turbidity measurements into suspended sediment concentrations ( $\mathrm{mg}$ dry $\mathrm{wt} \mathrm{l}^{-1}$ ). Fluorescence measurements were not calibrated against extracted chl $a$, and thus are expressed as relative fluorescence units. Current velocity distributions were measured using a shipboard, downward-looking RD
Instruments 1.2 MHz Broadband Acoustic Doppler Current Profiler (ADCP), with $0.5 \mathrm{~m}$ vertical resolution. Current velocities in $0.5 \mathrm{~m}$ bins were profiled through the water column, from $2 \mathrm{~m}$ below the surface to within $1 \mathrm{~m}$ of the bottom. Hydrostations on the axial transect were spaced at approximately $7 \mathrm{~km}$ intervals, with 11 stations conducted through the ETM region (Fig. 1). The location of the ETM was determined from an axial salinity and turbidity contour map produced after the axial survey. The position of the ETM time-series station shifted between cruises (Fig. 1) due to changes in freshwater input from the Susquehanna River (Sanford et al. unpubl.).

Fine-scale vertical estimates of zooplankton were made with the Tracor Acoustical Profiling System (TAPS-6). The unit is self-contained and internally records time, temperature, depth and acoustical volume back-scattering strength $(\mathrm{Sv})$ at 6 frequencies $(265,420,700,1100,1850$ and $3000 \mathrm{kHz})$. The acoustical principles, signal and data processing methods used to estimate zooplankton abundance with multifrequency acoustical measurements such as are made with the TAPS are described in Holliday \& Pieper (1995). When compared to net-collected samples, TAPS-6 gives reasonable estimates of zooplankton abundance, size distribution and biomass (Pieper \& Holliday 1984, Costello et al. 1989, Napp et al. 1993, Barans et al. 1997). We mounted TAPS on the CTDrosette system where concentrically focused transducers ensonified a $0.01 \mathrm{~m}^{3}$ volume centered approximately $1.5 \mathrm{~m}$ from the transducer surface. The small particles that scatter sound at these frequencies in marine environments are usually distributed randomly in the volume near the acoustical sensor. An echo from these randomly distributed particles is a sound wave which is itself characterized by random parameters. If one is to extract a size or an abundance as descriptors of the particle field, an estimate of the power spectrum of the acoustical echo (pressure wave) is needed. A Fourier transform of a set of random echos is also random. Under certain conditions of statistical stationarity, an appropriately long ensemble average of the Fourier transforms of sequential, independent echoes will converge to the desired power spectrum (Holliday 1977, Holliday \& Pieper, 1995). The number of such independent estimates that need to be averaged depends on the level of volume scattering encountered, the measurement system's noise floor, the patch and layer structure present, the degree of heterogeneity of the assemblage being studied, the rate at which the sensor is profiled through the water column, and the precision and accuracy of the answer desired in an estimate of the size-abundance spectra for the plankton present. In our experience, averaging between 8 and 24 echo spectra provides an adequate estimate of the reverber- 
ant power spectrum at a single depth in the open sea, the coastal ocean and a variety of lakes, rivers and estuaries. In this study, we programmed the TAPS-6 to collect and estimate the echo power spectra from 24 independent measurements of reverberation at each frequency at each depth sampled. This requires about $4 \mathrm{~s}$ and determines the rate at which one can make a cast while retaining the desired vertical resolution of the structure present.

The volume scattering strengths at each frequency were transformed with a non-linear least squares (NNLS) algorithm to calculate the number and sizes of the particles in the ensonified volume (Lawson \& Hanson 1974, Holliday 1977, Holliday \& Pieper 1995). In most marine and estuarine environments, the lower size limit of zooplankton detected by a TAPS is approximately $0.05 \mathrm{~mm}$ Equivalent Spherical Radius (ESR) or $0.225 \mathrm{~mm}$ in length. The ESR is simply the radius of a sphere that would contain the displacement volume of a particle. The upper size limit is approximately $4 \mathrm{~mm}$ ESR or approximately $20 \mathrm{~mm}$ in length. Both the upper and lower size limits can vary with the numerical abundance of the animals present, but to first order, the frequency band covered by a multifrequency sensor such as the TAPS sets the minimum and maximum sizes that it will sense quantitatively.
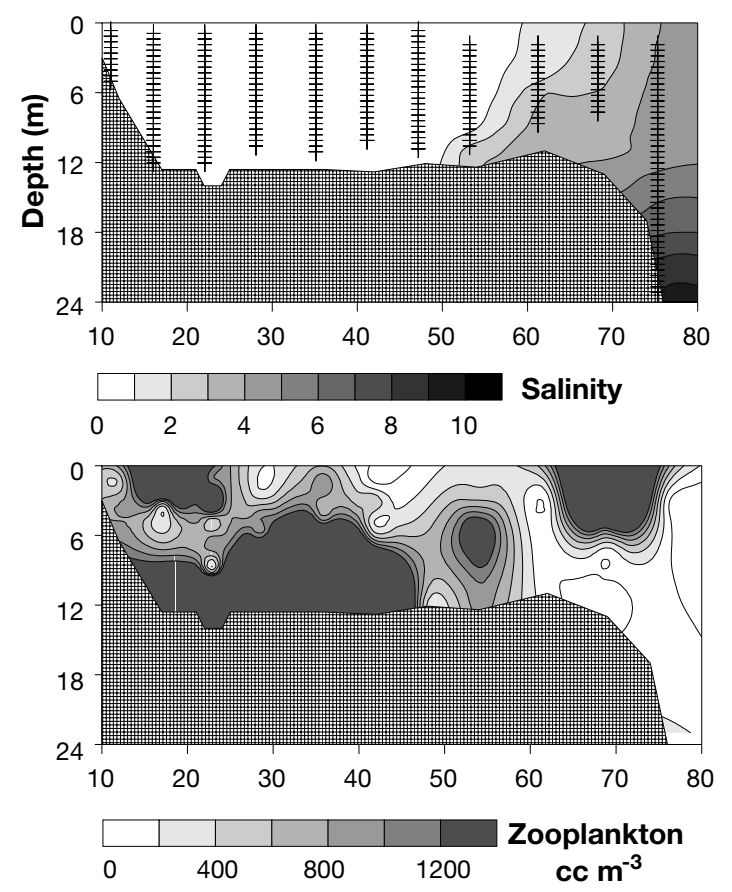

A portion of the spectrum of zooplankton sizes present was also collected with $10 \mathrm{l}$ Niskin bottles for qualitative comparisons of the small copepod species (Eurytemora, Acartia) that were responsible for the acoustically determined biomass peaks. The Niskin bottles were approximately within $1 \mathrm{~m}$ of the acoustic transducers and collected a water sample at the same time we were collecting acoustic data. The Niskin bottles were drained through a $35 \mu \mathrm{m}$ mesh, the sample preserved in $5 \%$ formalin, and the animals identified, counted and measured in the laboratory. Past studies have shown that estimates of $<2 \mathrm{~mm}$ zooplankton from Niskin bottle and net tow collections were similar (Houde \& Lovdal 1985).

It is difficult to collect 'traditional' zooplankton samples (net tows, pump and Niskin samples) to compare to acoustic zooplankton estimates. This is especially true in the ETM region where there are sharp vertical gradients in zooplankton and short-term tidal variability in the distribution of zooplankton communities. Traditional zooplankton collections do not sample the same water sensed by the TAPS. There is both vertical and horizontal separation of the acoustic volume sampled by TAPS and the collected zooplankton. TAPS collects about 6 sets of echoes at each frequency every second, thus the TAPS integrates its zooplankton esti-
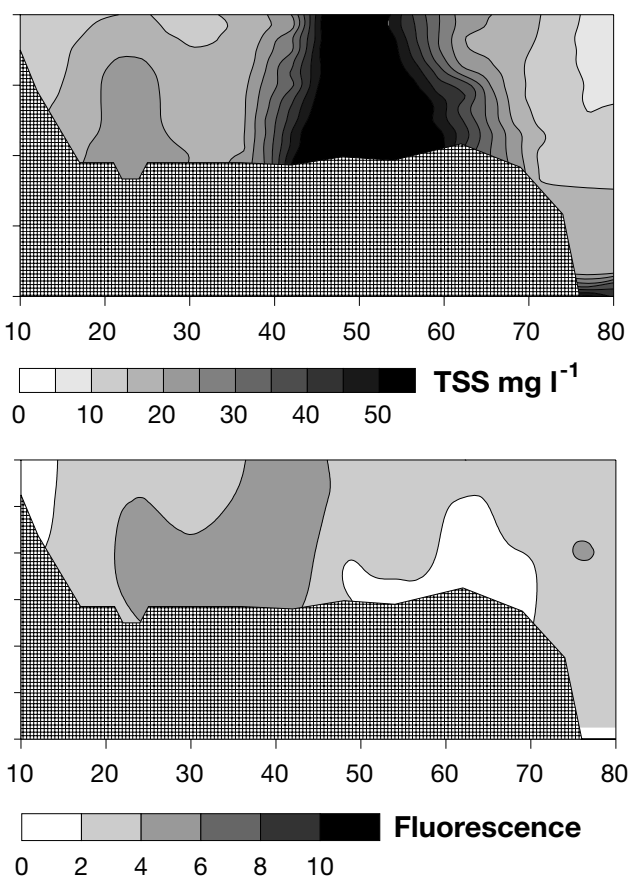

Distance From Top of Bay (km)

Fig. 2. May 1996 axial transect of: salinity; TSS (total suspended sediments; mg $\mathrm{l}^{-1}$ ); zooplankton biomass (cc $\mathrm{m}^{-3}$ ); and chlorophyll fluorescence. Distance plotted from the top of the Bay in $\mathrm{km}$. Stations and depths sampled indicated by vertical bars and hatches 
mates over a much larger volume of water than collected by pumps, Niskin bottles or net tows. In addition, the lower frequencies of TAPS can detect larger zooplankton such as the abundant mysids and amphipods of the ETM which can avoid capture by nets, pumps and bottles. All of these factors make quantitative comparisons between acoustics and pumps/nets/ bottles difficult (Pieper \& Holliday 1984, Costello et al. 1989). Our purpose here was to collect zooplankton to determine the identification of small copepod species that were contributing to particular acoustic biomass maxima and to compare the pattern (surface, middle, near-bottom Niskin samples) and relative magnitudes of the acoustic and Niskin bottle zooplankton estimates.

\section{RESULTS}

\section{Axial transects}

In May, maximum concentrations of total suspended sediments (TSS), fluorescence and acoustic estimates of zooplankton biomass were located near, or up-Bay of the 1 isohaline (Fig. 2). Eurytemora was the dominant copepod in the ETM region. Suspended sediments exhibited the highest concentrations near the
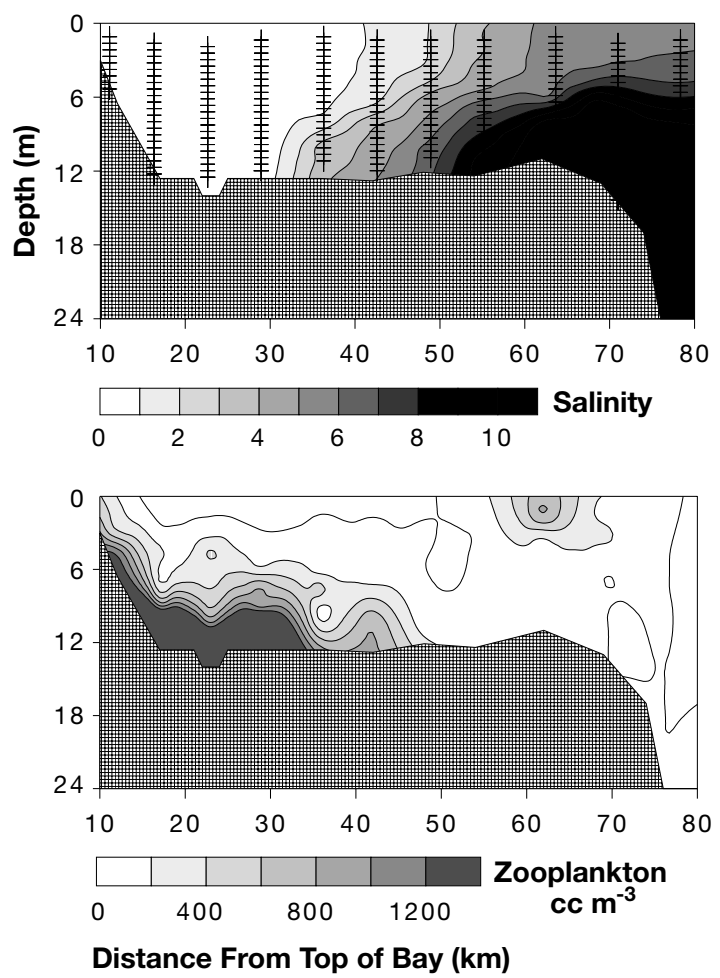

salt wedge. Fluorescence and near-bottom zooplankton maxima were up-Bay of the salinity front. Compared to our measurements in July and October, acoustical estimates of zooplankton biomass were highest in May. Previous studies on seasonal changes in zooplankton in the low salinity portions of Chesapeake Bay have also found maximum zooplankton abundances in spring (Herman et al. 1968, Heinle \& Flemer 1975, White \& Roman 1992).

In July as in May, we found the highest concentrations of suspended sediments and zooplankton near, or up-Bay of the salt intrusion (Fig. 3). The zooplankton biomass maxima near the bottom was dominated by Eurytemora whereas the surface zooplankton maxima between 60 and $70 \mathrm{~km}$ from the head of the Bay was composed primarily of the calanoid copepod Acartia tonsa. Peak concentrations of zooplankton were located up-Bay of peak concentrations of suspended sediments. Fluorescence was highest in July as compared to our measurements in May and October, with the highest fluorescence just upstream and downstream of the turbidity maximum (Fig. 3).

In October we found the highest zooplankton biomass located near the bottom, at the toe of the salt wedge approximately $40 \mathrm{~km}$ from the top of the Bay (Fig. 4). Acoustic estimates of zooplankton biomass were lowest in October when compared to our mea-
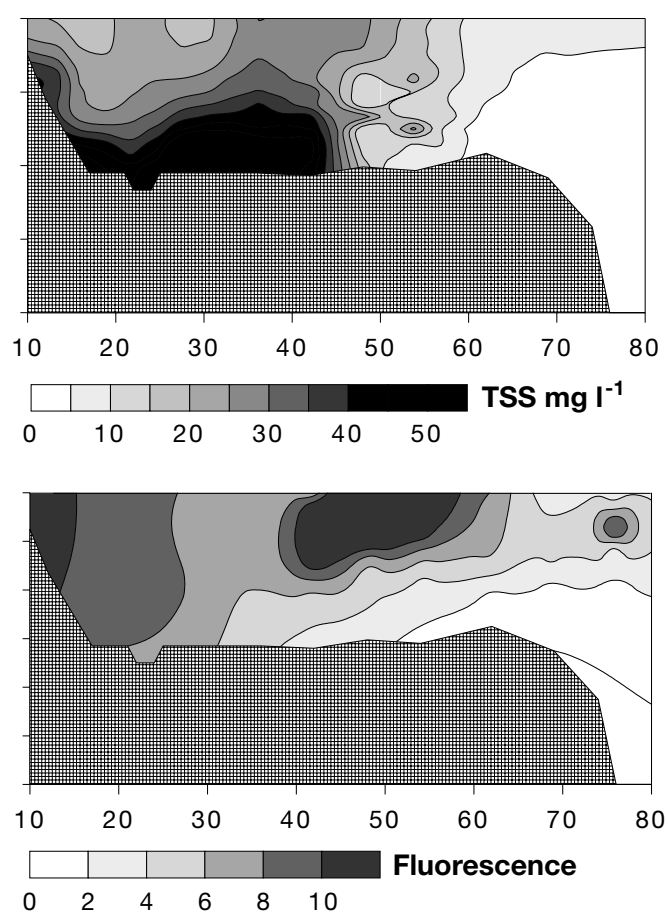

Fig. 3. July 1996 axial transect of; salinity, TSS (total suspended sediments; mg l ${ }^{-1}$ ); zooplankton biomass (cc m ${ }^{-3}$ ); and chlorophyll fluorescence. Distance plotted from the top of the Bay in $\mathrm{km}$. Stations and depths sampled indicated by vertical bars and hatches 

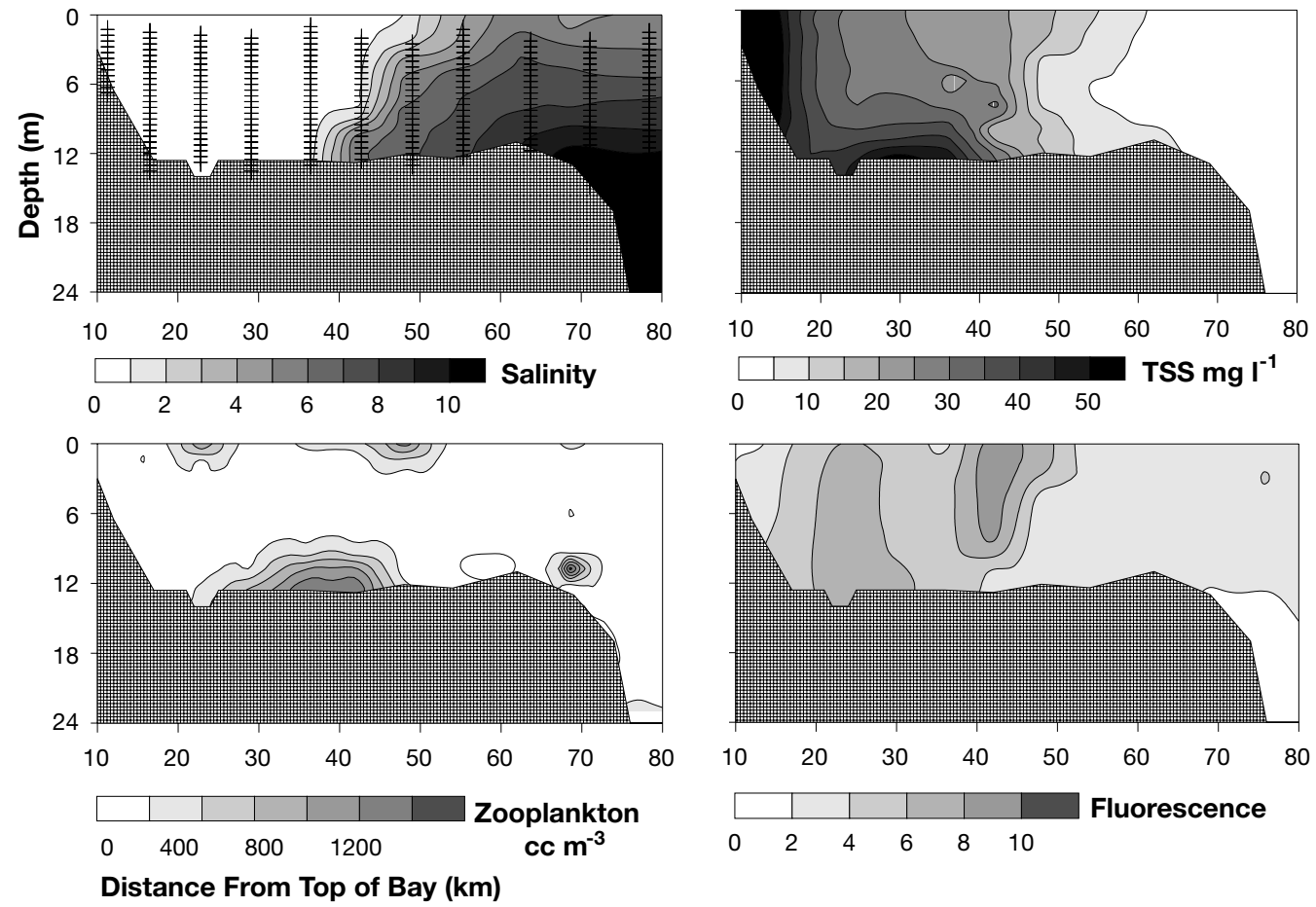

Fig. 4. October 1996 axial transect of: salinity; TSS (total suspended sediments; $\mathrm{mg} \mathrm{l}^{-1}$ ); zooplankton biomass (cc $\mathrm{m}^{-3}$ ); and chlorophyll fluorescence. Distance plotted from the top of the Bay. Stations and depths sampled indicated by vertical bars and hatches

surements in May and July. Maximum concentrations of suspended sediments in October were up-Bay of the maxima of zooplankton and fluorescence. In both October and July, the salt wedge appeared to retain water which exhibited high fluorescence in the upper Bay (Figs. 3 \& 4).

\section{Time series}

Repeated measurements in the ETM region were done to document diel and tidal variability in both physical and biological variables. In May, equipment problems limited our time series observations. The measurements we did complete indicated that large variations in seston occurred as the salt wedge was advected past our fixed station. Maximum concentrations of suspended sediments, fluorescence and zooplankton occurred during mid-ebb and mid-flood tides (Fig. 5). Note that with greater density stratification associated with the salt wedge, TSS, zooplankton and fluorescence were reduced in the upper water column. We found over an order of magnitude change in total water column zooplankton (primarily Eurytemora) biomass over the May time series.

In July, increases in the water column concentrations of TSS and zooplankton occurred during both flood and ebb tides (Fig. 6) with greater increases during ebb. Increases in acoustic estimates of zooplankton biomass in the upper water appeared to lag increases in suspended sediments, with the highest water column concentrations of zooplankton occurring at the end of the time series when suspended sediments were decreasing. Changes in the vertical distribution of zooplankton biomass did not appear to be associated with the light cycle.

Prior to the October cruise, there was enhanced freshwater input from the Susquehanna River (Sanford et al. unpubl.). Thus during our October time series, the salt wedge was confined to a lower portion of the water column as compared to May and July (Fig. 7). As a consequence, most of the water column was fresh riverine water. The pattern of suspended sediment variation was similar to that observed in July. The reduced stratification in the upper water column may have resulted in greater upward mixing of suspended sediments. The highest acoustic estimates of zooplankton biomass occurred during maximum ebb tide at approximately midnight (Fig. 7). Fluorescence generally decreased over the time series, with the highest fluorescence at the first low tide when salinities were minimum.

A closer examination of the October time-series data suggests that changes in the biomass of zooplankton in the water column were the result of both advective and local processes. As an indicator of the salt wedge, we 

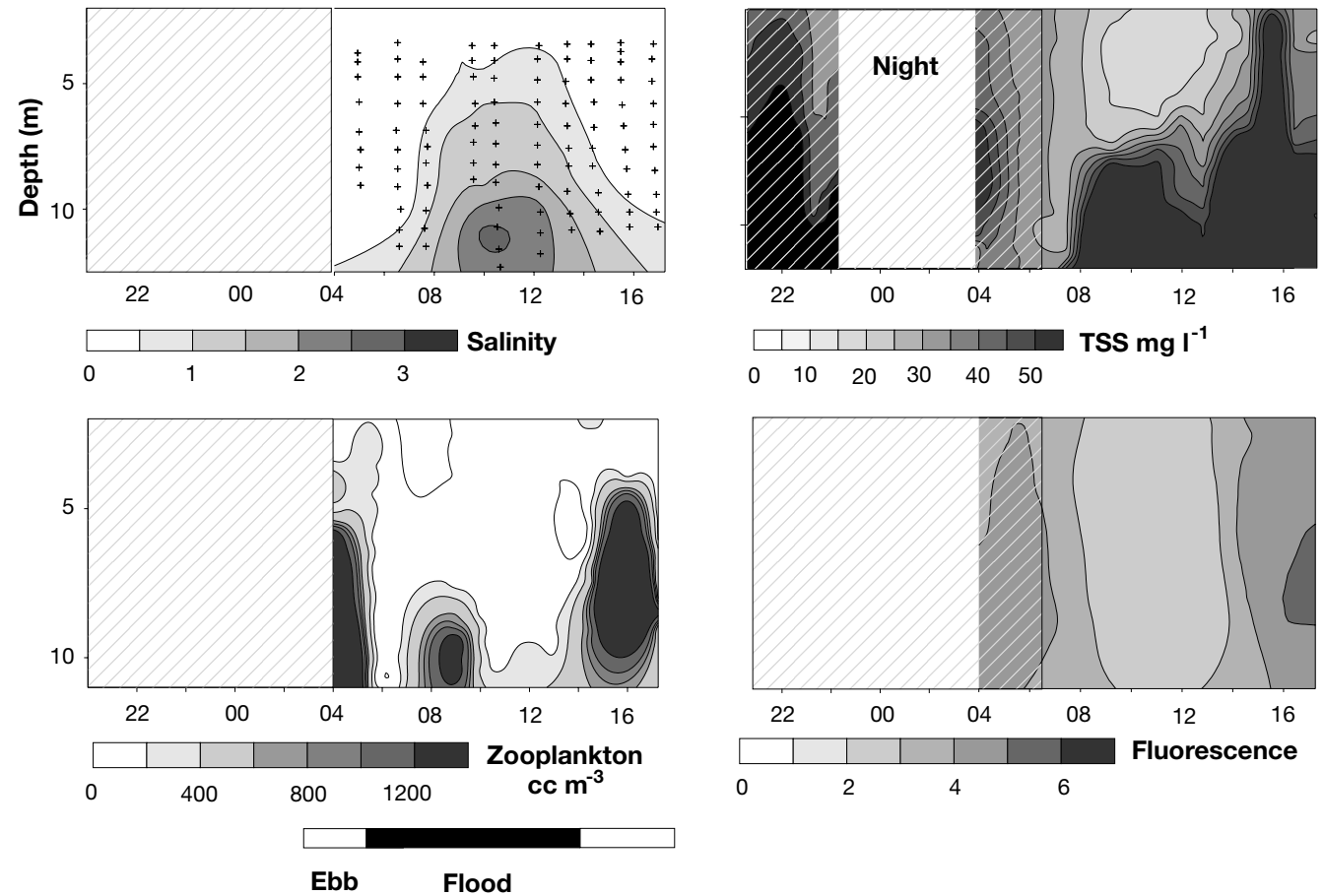

Fig. 5. May 1996 time-series study in the Chesapeake Bay ETM of: salinity; TSS $\left(\mathrm{mg} \mathrm{l}^{-1}\right)$; zooplankton biomass $\left(\mathrm{CC} \mathrm{m}^{-3}\right)$; and chlorophyll fluorescence over time (h). Hatched area indicates night. White and black bars at bottom indicate periods of flood and ebb tides. Depths sampled indicated by crosses
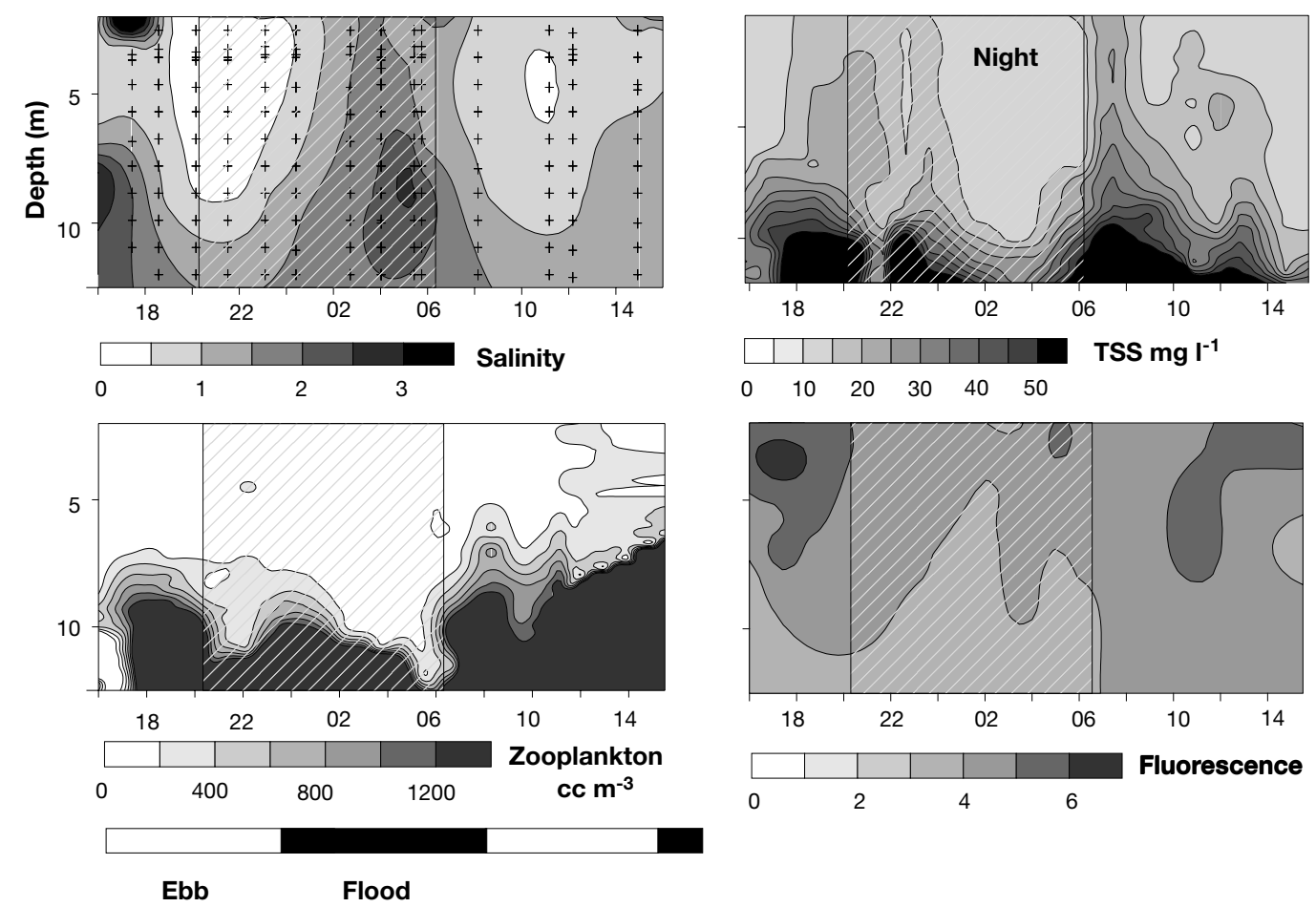

Fig. 6. July 1996 time series study in the Chesapeake Bay ETM of: salinity; TSS $\left(\mathrm{mg} \mathrm{l}^{-1}\right)$; zooplankton biomass $\left(\mathrm{Cc} \mathrm{m}^{-3}\right)$; and chlorophyll fluorescence over time $(\mathrm{h})$. Hatched area indicates night. White and black bars at bottom indicate periods of flood and ebb tides. Depths sampled indicated by crosses 

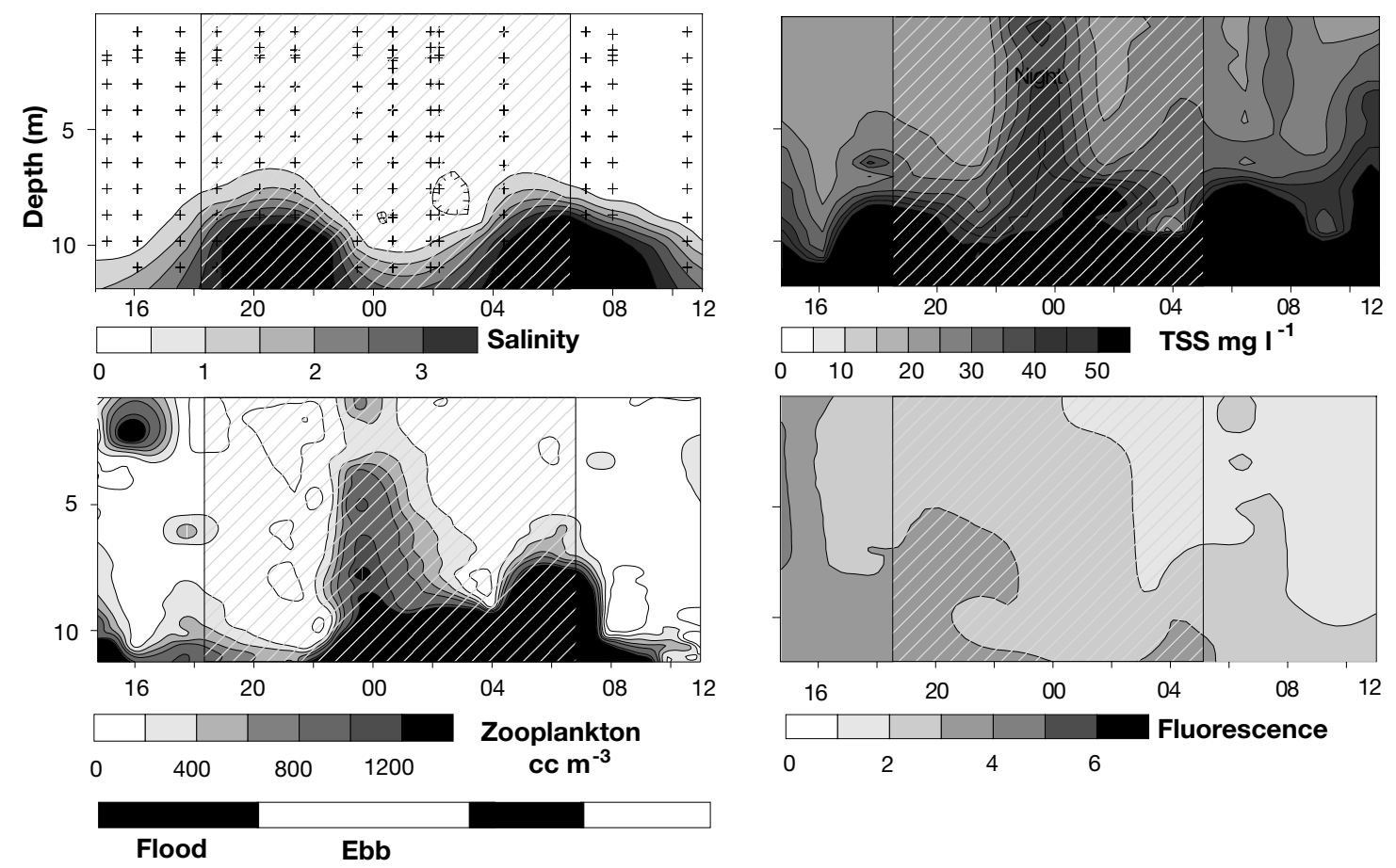

Flood

Ebb

Fig. 7. October 1996 time series study in the Chesapeake Bay ETM of: salinity; TSS $\left(\mathrm{mg} \mathrm{l}^{-1}\right)$; zooplankton biomass $\left(\mathrm{cc} \mathrm{m}^{-3}\right)$; and chlorophyll fluorescence over time (h). Hatched area indicates night. White and black bars at bottom indicate periods of flood and ebb tides. Depths sampled indicated by crosses

compared the salinity of the bottom water to the total integrated water column concentration of suspended sediments, and to both zooplankton with sizes (ESR) that were $<3 \mathrm{~mm}$ (ca $15 \mathrm{~mm}$ in length) and to total zooplankton biomass (integrated over those with zooplankton lengths ranging from approximately 0.225 to $20 \mathrm{~mm}$ in length, Fig. 8). Maxima in total integrated zooplankton biomass occurred during ebb and flood tides when stronger currents could have resuspended zooplankton from below our deepest TAPS measurement (generally $1 \mathrm{~m}$ off the bottom) into the water column. The largest difference between the 2 zooplankton fractions (the abundance of the 3 to $20 \mathrm{~mm}$ long zooplankton/fish larvae) occurred during flood tide rather than during the night. Maxima and minima in integrated zooplankton biomass did not appear to be influenced by photoperiod. The lack of apparent diel vertical migration by zooplankton is also supported by data on the median depth of zooplankton biomass (Fig. 9). Note that most of zooplankton biomass was located in the lower third of the water column both during the day and night. There was some suggestion that distribution of zooplankton biomass moved up in the water column during periods of slack water. The depth of the median concentration of suspended sediments was slightly deeper $(8 \mathrm{~m})$ than the median depth of zooplankton biomass $(7 \mathrm{~m})$.
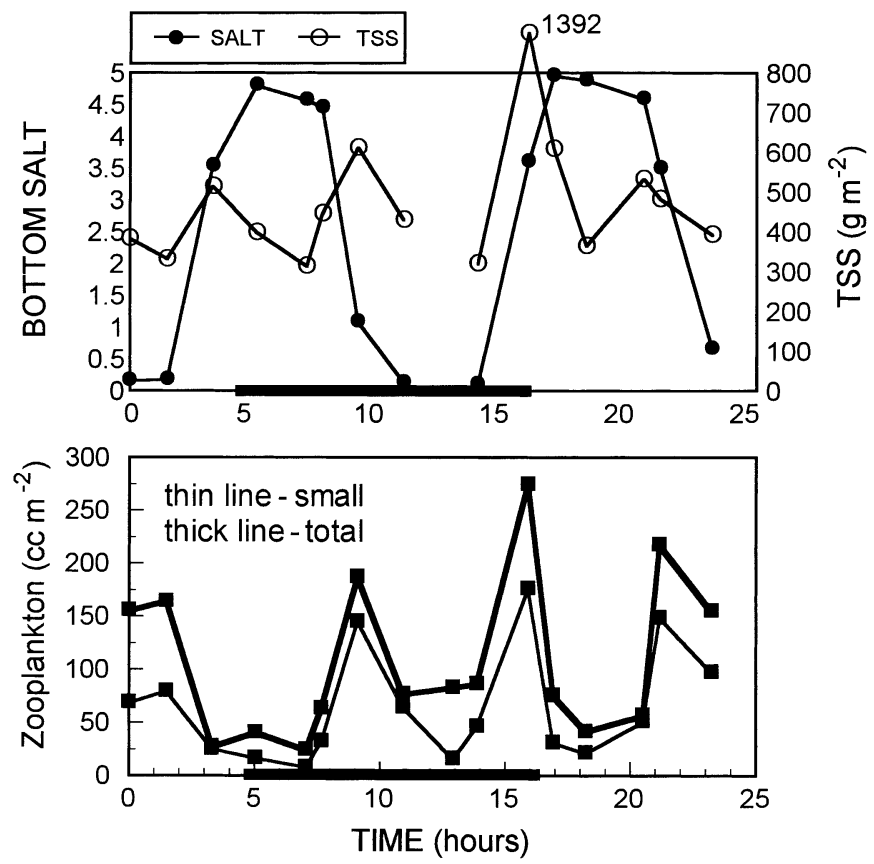

Fig. 8. October 1996 time-series study in the Chesapeake Bay ETM of: bottom salinity; total water column suspended sediments $\left(\mathrm{g} \mathrm{m}^{-2}\right)$; and total water column zooplankton biomass $\left(\mathrm{cc} \mathrm{m}^{-2}\right)$. Thin line represents zooplankton $>0.05$ to $0.72 \mathrm{~mm}$ ESR (equivalent spherical radius), thick line represents zooplankton $>0.05$ to $4 \mathrm{~mm}$ ESR. Black bar designates night 

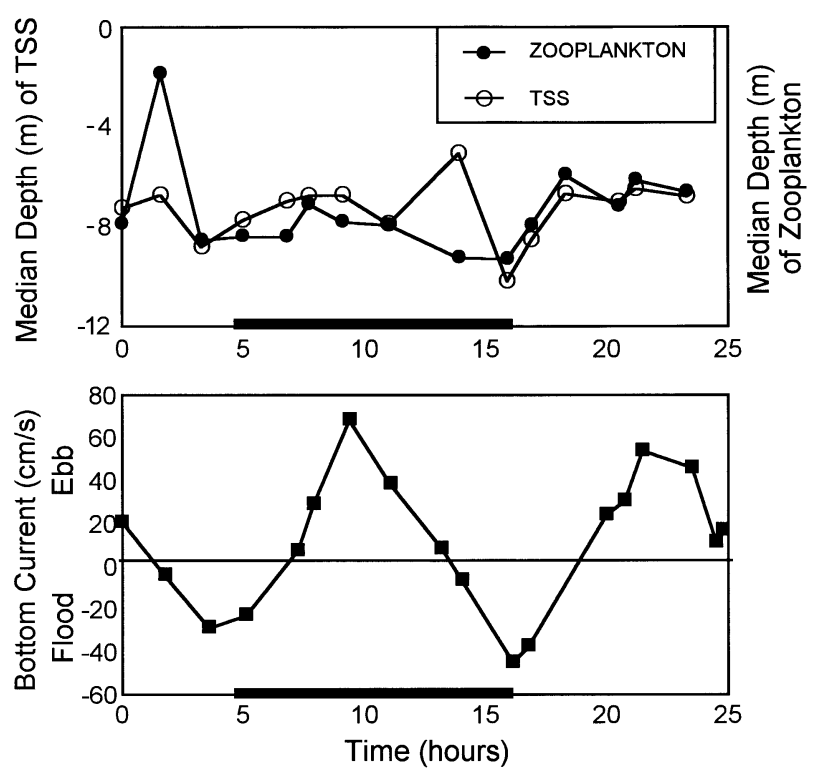

Fig. 9. October 1996 time-series study in the Chesapeake Bay ETM of: median depth $(\mathrm{m})$ of acoustically derived zooplankton (>0.05 to $0.72 \mathrm{~mm}$ ESR) biomass; median depth $(\mathrm{m})$ of total suspended sediments; and bottom current $\left(\mathrm{cm} \mathrm{s}^{-1}\right)$. Black bar designates night

\section{DISCUSSION}

Zooplankton abundance and biomass in the Chesapeake Bay ETM estimated with TAPS, and Niskin bottles show maximum concentrations $>200$ copepods $\mathrm{l}^{-1}$ or $>15 \mathrm{cc} \mathrm{m}^{-3}$ biovolume. While high compared to shelf

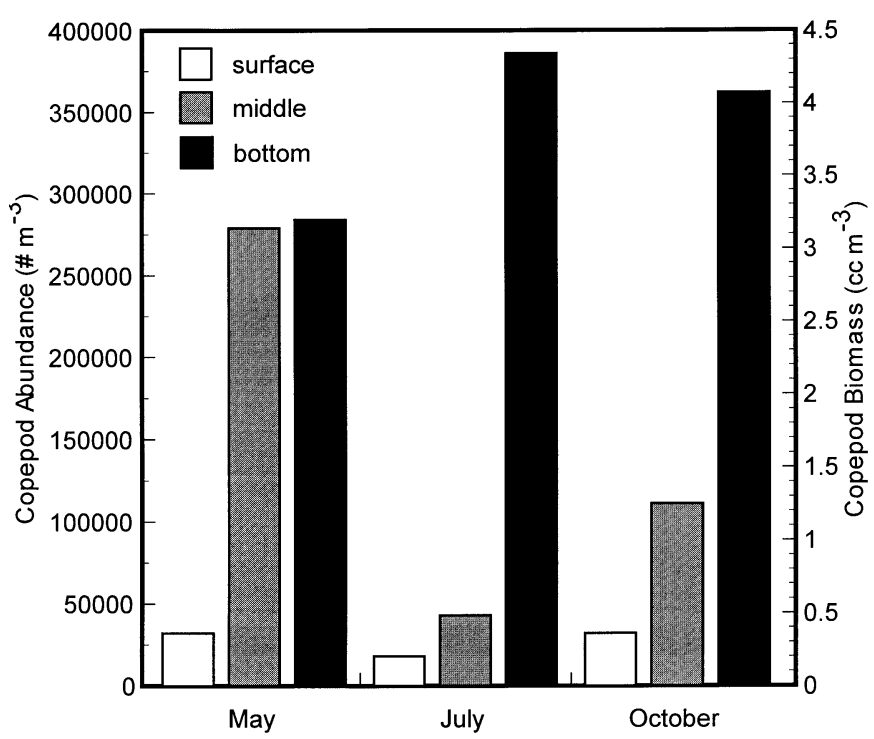

Fig. 10. Abundance of adult copepods in surface $(1 \mathrm{~m})$, middle $(5 \mathrm{~m})$ and bottom $(10 \mathrm{~m})$ waters of the ETM in May, July and October 1996. Biovolume estimates were calculated by using an average of $0.015 \mathrm{~mm}^{-3}$ copepod $^{-1}$ and open ocean waters, these zooplankton concentrations have been measured in estuarine waters, especially in ETM regions (Herman et al. 1968, Bousfield et al. 1975, Heinle \& Flemer 1975, Castel \& Veiga 1990, Kimmerer et al. 1998, Morgan et al. 1997). Most zooplankton sampling programs have used net collections which integrate maximum and minimum zooplankton concentrations within the water column. A great advantage of using technology such as TAPS is the ability to make rapid zooplankton measurements at fine-scale intervals (in this study every $0.5 \mathrm{~m}$ in the vertical). Thus we found quite high zooplankton concentrations at particular depths. Often these zooplankton maxima were close to the bottom. In other estuarine systems, researchers have found that copepod concentrations immediately off the bottom can be several orders of magnitude greater than concentrations in surface waters and mid-depths (Herman et al. 1968, Heinle \& Flemer 1975, Fulton 1984).

We were concerned that the high suspended sediment concentrations might have been included in the acoustic estimates of zooplankton. The lower limit of particle size detection of TAPS-6 is approximately $100 \mu \mathrm{m}$ equivalent spherical diameter. Schubel (1968) in a study of the Chesapeake Bay ETM found that the mean size of suspended particles was 5 to $8 \mu \mathrm{m}$ in diameter. During maximum tidal flow, larger particles (12 to $20 \mu \mathrm{m}$ diameter) were resuspended into the water column. Thus the suspended sediments of the Chesapeake Bay ETM region are too small to be detected by the TAPS-6 as individual particles. Several observations suggest that these sediment particles were not being measured as zooplankton with the TAPS system. Peak estimates of zooplankton biovolume often were different in time and space than maxima in suspended particles (Figs. 2 to 7 ). In addition, sediments are solids which support shear waves and are typically modeled as elastic scatterers (Faran 1951). The frequency dependence of scattering from sediments differs from that of crustaceans. These differences can be quantitatively used to apportion abundance, by size, between different classes of scatterers; i.e., fluid spheres $=$ crustacean zooplankton and elastic scatters = sediments (Holliday 1977). We used models for both sediment particles and crustaceans in an inverse calculation to determine size and abundance for elastic and crustacean types of scatterers. These inverse calculations revealed that most (>90\%) of the scattering detected by TAPS in the Chesapeake Bay ETM was due to crustacean zooplankton.

An example of copepod (predominantly Eurytemora) counts from Niskin bottle collections in the surface, mid-water column (6 m) and $2 \mathrm{~m}$ off the bottom, show that the highest abundances were near the bottom during all 3 seasons studied (Fig. 10). The estimated biovolume (using an average size of $0.015 \mathrm{~mm}^{3}$ cope- 
$\operatorname{pod}^{-1}$ ) of Niskin bottle-collected copepods is of the same order of magnitude, but generally lower, than total zooplankton biovolume estimated with TAPS. This lower estimate is likely due to large zooplankton which avoid the Niskin bottles but are measured with the in situ TAPS. The observation that both mysids and amphipods are often the dominant prey item in the stomachs of juvenile white perch and striped bass in the ETM (Boynton et al. 1997) suggests that high densities of these macrozooplankton exist in the ETM and likely contribute to the high zooplankton biomass estimated by TAPS.

The TAPS estimates of zooplankton biomass are approximately $10 \times$ higher than multifrequency acoustic estimates of zooplankton biomass estimates in the Southern California Bight (Costello et al. 1989) and Gulf Stream (Napp et al. 1993) but similar in range to multifrequency acoustic estimates of zooplankton biomass from a moored station off Los Angeles, CA (Holliday \& Pieper 1995) and in an estuarine inlet of South Carolina (Barans et al. 1997). A similar order of magnitude difference in zooplankton biomass between neritic and oceanic zooplankton has been found in the more traditional net collections of zooplankton (Grice \& Hart 1962).

The general pattern exhibited in the axial transects through the Chesapeake Bay ETM is that sediments and zooplankton were in higher concentrations at, or just up-Bay, of the salt wedge (1 isohaline). The highest zooplankton biomass generally occurred near the bottom at the toe of the salt wedge. The near-bottom convergence zone (Boynton et al. 1997) associated with this feature likely concentrates sediments and zooplankton (primarily Eurytemora) similar to the trapping of buoyant particles at surface fronts. The lack of apparent vertical migration, carrying eggs until they are ready to hatch and the ability to consume phytoplankton, protozoa and detritus (Heinle et al. 1977, Boak \& Golder 1983, White \& Roman 1992) all may allow Eurytemora to persist at high concentrations in the Chesapeake Bay ETM. In addition, living in the near-bottom highly turbid waters of the ETM region may provide the Eurytemora a refuge from visual predators.

Zooplankton abundance in the ETM region of Chesapeake Bay appears to be influenced by both advective and local processes. Zooplankton biomass at the fixed ETM station increased/decreased with the tidal excursion of the salt wedge. The highest zooplankton concentrations usually occurred during periods of lower salinity. In addition, both total water column zooplankton concentration and the vertical distribution of zooplankton biomass appeared to be influenced by currents. We often found that during maximum ebb and flood tides, zooplankton biomass in the mid and upper water column increased. A similar pattern was observed for sediments, suggesting that both sediments and zooplankton were resuspended into the water column by tidal currents. Peak tidal currents of 60 to $80 \mathrm{~cm} \mathrm{~s}^{-1}$ occur in this region, with ebb currents generally greater that flood currents (Fig. 9). These tidal currents are of sufficient magnitude to resuspend zooplankton concentrated in the bottom waters (Castel \& Veiga 1990). At our fixed station time series, lower salinities and reduced density stratification (upstream of the salt wedge) during ebb tide likely result in enhanced turbulence and the resuspension of particles and plankton in the water column (Figs. 5, 6 \& 7, Geyer 1993).

During the time series in the 3 seasons, we did not find any evidence that the vertical distribution of zooplankton was influenced by photoperiod. Eurytemora, the dominant copepod in the Chesapeake Bay ETM, has not exhibited diel vertical migration in a variety of other estuarine systems (Castel \& Veiga 1990, Hough \& Naylor 1991, Simenstad et al. 1994, Kimmerer et al. 1998). The highly turbid conditions of ETM regions may not provide the proper light intensities to cue vertical migration behavior induced by photoperiod. In addition, vertical migration in response to light is not a good strategy for remaining in ETM regions. If zooplankton migrated to surface waters they would be carried out of the ETM in the seaward-flowing fresh surface waters.

Eurytemora can be regarded as an epibenthic copepod (Jones et al. 1990). Its propensity to remain near the bottom in the Chesapeake Bay ETM region where there are landward residual currents enhances the ability of Eurytemora to remain in the ETM region. Castel \& Veiga (1990) suggested that Eurytemora acted like passive particles in the Gironde estuary. They found that Eurytemora could not alter its position against currents: the copepods had average sinking rates of $2 \mathrm{~mm} \mathrm{~s}^{-1}$, and the concentration of suspended sediments and Eurytemora were highly correlated. We also found that suspended sediments and zooplankton biomass were highly correlated $\left(\mathrm{r}^{2}=0.52, \mathrm{n}=299\right.$, $\mathrm{p}<0.05$ for July and $\mathrm{r}^{2}=0.59 ; \mathrm{n}=313$; $\mathrm{p}<0.05$ for October time-series) in the Chesapeake Bay ETM (Fig. 11). Thus the hydrodynamic processes that resuspend, advect and trap suspended sediments in the ETM likely have the same effects on zooplankton. If the higher sediment and zooplankton concentrations were associated with freshwater inputs, there would be significant negative relationships between salinity/sediments and salinity/zooplankton. We did not find such relationships (Fig. 11) suggesting that in situ processes such as resuspension and the trapping of sediments and zooplankton with the convergent flows at the salt wedge predominated in the Chesapeake Bay ETM. 
Our understanding of the mechanisms of particle trapping and maintenance in the Chesapeake Bay is preliminary. Our investigations were limited to 3 cruises in 1996, which was an unusually wet year (Sanford et al. unpubl.). Based on our preliminary findings, we have developed a conceptual model for particle trapping mechanisms and phase lags in the Chesapeake Bay ETM which could serve as a focal point for future research (Fig. 12). Note that the gravitational circulation concentrates zooplankton and sediments at the salt front. Sediments and zooplankton are resuspended by tidal currents, with greater water column concentrations during the asymetrical ebb tide. Sediments and zooplankton are resuspended to the height of the pycnocline. There is a phase lag whereby increases in zooplankton 'lead' increases in sediment because the zooplankton are more readily resuspended by the currents. When there is a seaward wind added to a flood tide, the gravitational circulation is enhanced, moving the toe of the salt front landward, faster that the pool of erodable sediments that defines the ETM. This condition results in a temporary separation between zooplankton and suspended sediments.

The Chesapeake Bay ETM is approximately 10 to $30 \mathrm{~km}$ in length or roughly 4 to $13 \%$ of the total length of the bay. Although small, this portion of Chesapeake Bay is an important spawning zone for anadromous fish such as striped bass, white perch and river herrings (Boynton et al. 1997). Our data suggest that the ETM of Chesapeake Bay acts as an entrapment zone for sediments and zooplankton. Zooplankton abundances are over an order of magnitude greater in the
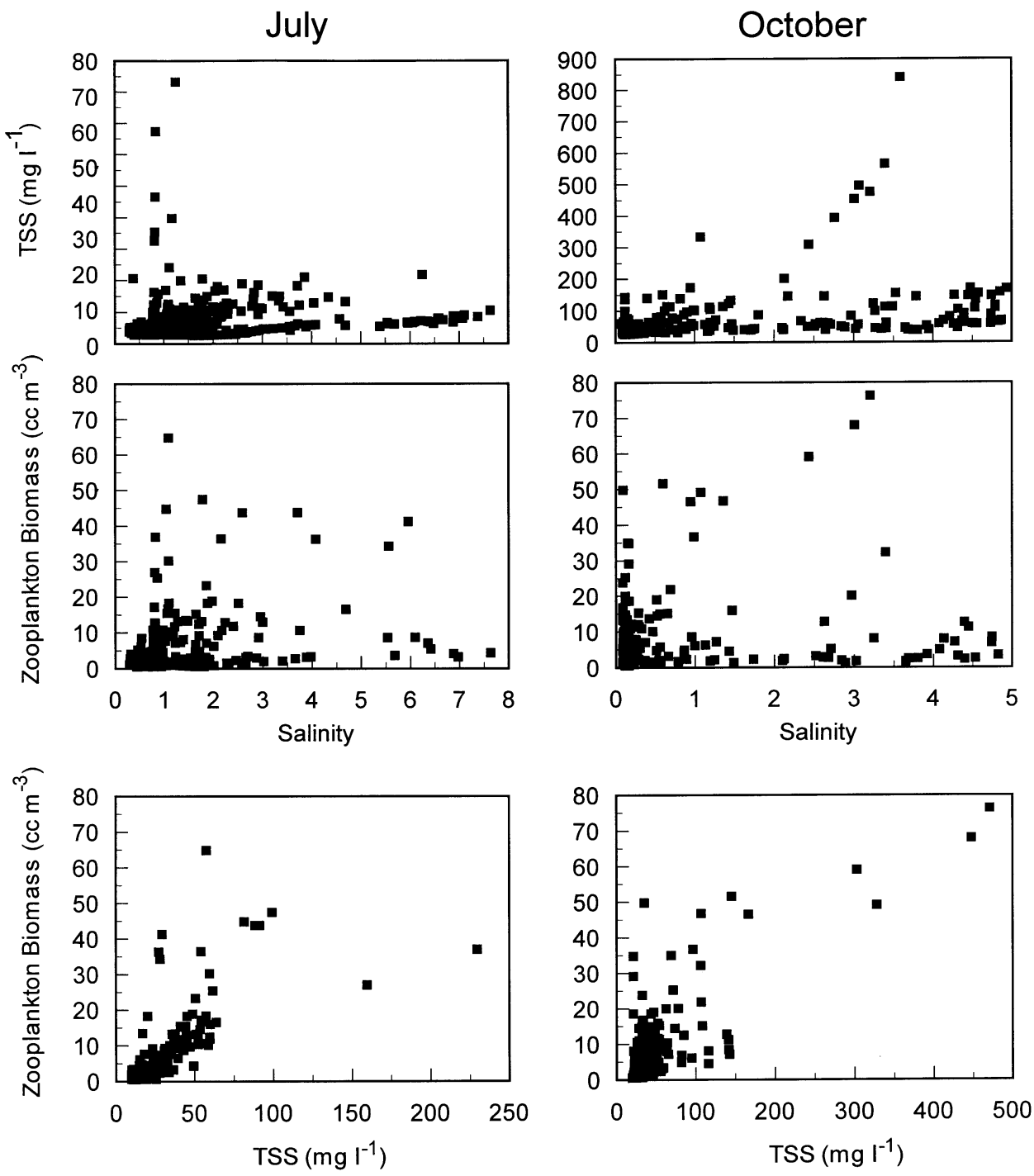

Fig. 11. Comparisons of acoustic estimates of zooplankton biomass, salinity and total suspended sediments (TSS) in the ETM region of Chesapeake Bay during the July and October 1996 time-series studies 
a) Gravitational Circulation (GC) Alone

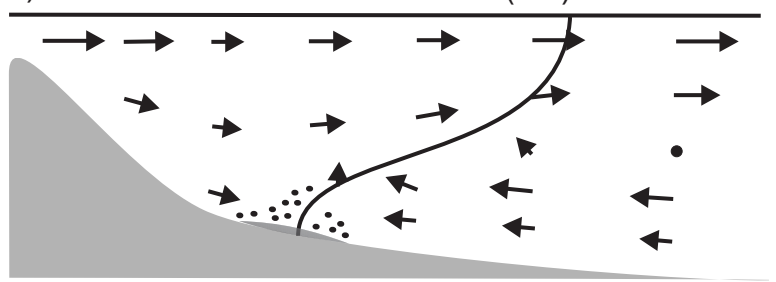

c)

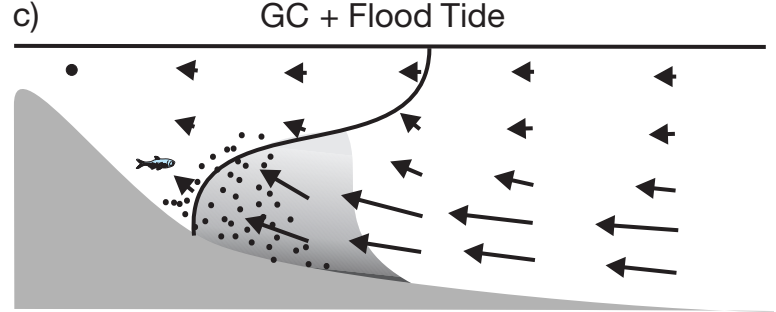

b)

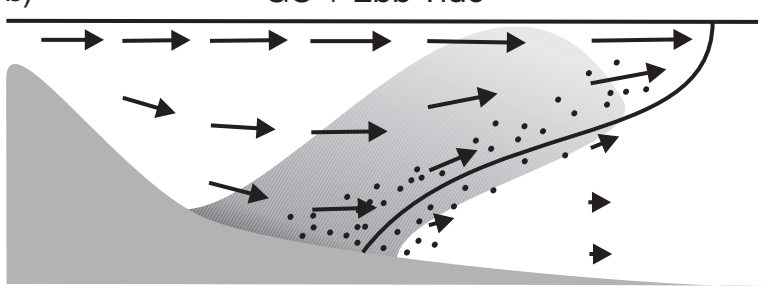

d)

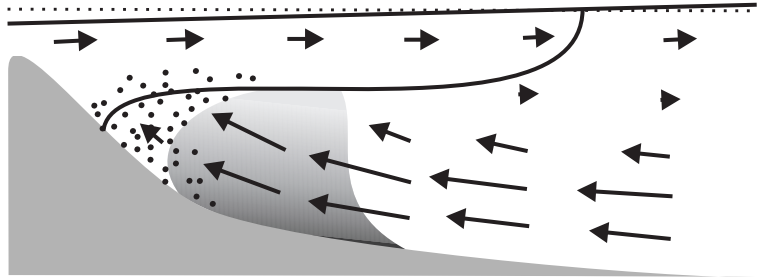

Fig. 12. Conceptual diagram of particle and zooplankton Eurytemora affinis trapping in the Chesapeake Bay ETM. The river is to the left and the sea is to the right. Heavy curved line represents the 1 psu isohaline, arrows current vectors, dots zooplankton, and the shading suspended sediment. (a) Near-bottom convergence of the gravitational circulation (GC) at the toe of the salt front collects settling particles and zooplankton, but everything is concentrated near the bottom because the currents are too weak for resuspension. (b) The GC enhances ebb tidal currents upstream of the salt front, resulting in resuspension of sediments and zooplankton high into the water column. The GC opposes ebb tidal currents below the salt front, such that only settling occurs. Zooplankton slightly lead sediment because they are more readily resuspended. (c) The GC enhances flood tidal currents below the salt front, resulting in resuspension of sediments and zooplankton, but only to the height of the pycnocline. Zooplankton again lead sediments. The GC opposes flood tidal currents above the salt front, with no resuspension. (d) A seaward wind circulation added to flood tidal currents and the GC further enhances resuspension below the salt front, but it also moves the toe of the salt front landward faster than the ETM and results in a temporary separation between zooplankton and suspended sediments

ETM compared to the surrounding area. The enhanced zooplankton concentrations in the ETM may be a persistent feature of Chesapeake Bay and likely serve to promote the survival of early life stages of anadromous fish which are also concentrated in the region (Boynton et al. 1997).

Acknowledgements. The assistance of A. Gauzens, C. Greenlaw, E. Houde, A. Sanford, A. Spear, S. Suttles and X. Zhang in the collection and reduction of data is gratefully acknowledged. We thank the Captain and crew of the ORV 'Cape Henlopen' for help and competence during the field program. This research was supported by NSF contract DEB-9412113 as part of the Land Margin Ecosystem Research Program. We thank Walter Boynton for his administrative and scientific leadership of the program. UMCES Contribution \# 3411.

\section{LITERATURE CITED}

Barans CA, Stender BW, Holliday DV, Greenlaw CF (1997) Variation in the vertical distribution of zooplankton and fine particles in an estuarine inlet of South Carolina. Estuaries 20:467-482

Berk SG, Brownlee DC, Heinle DR, Kling HJ, Colwell RR (1977) The importance of ciliates as a food source for marine planktonic copepods. Microb Ecol 4:27-37

Biggs RB (1970) Sources and distribution of suspended sedi- ment in Northern Chesapeake Bay. Mar Geol 9:187-201

Boak AC, Goulder R (1983) Bacterioplankton in the diet of the calanoid copepod, Eurytemora sp. in the Humber Estuary. Mar Biol 73:139-149

Bousfield EL, Filteau G, O'Neill M, Gentes P (1975) Population dynamics of zooplankton in the middle St. Lawrence Estuary. Estuarine Res 1:325-351

Boynton WR, Boicourt W, Brandt S, Harding L, Holliday Y, Jech M, Kemp M, Lascara C, Leach S, Madden A, Roman M, Sanford S, Smith E (1997) Interactions between physics and biology in the estuarine turbidity maximum (ETM) of Chesapeake Bay, USA. ICES CM 1997/S:11

Castel J, Veiga J (1990) Distribution and retention of the copepod Eurytemora affinis hirundoides in a turbid estuary. Mar Biol 107:119-128

Costello JH, Pieper RE, Holliday DV (1989) Comparison of acoustic and pump sampling techniques for the analysis of zooplankton distributions. J Plankton Res 11:703-709

Dauvin JC, Dodson JJ (1990) Relationship between feeding incidence and vertical and longitudinal distribution of rainbow smelt larvae (Osmerus mordax) in a turbid wellmixed estuary. Mar Ecol Prog Ser 60:1-12

Dodson JJ, Dauvin JC, Ingram RG, d'Anglejan B (1989) Abundance of larval rainbow smelt (Osmerus mordax) in relation to the maximum turbidity zone and associated macroplankton fauna of the middle St. Lawrence estuary. Estuaries 12:66-81

Faran JJ (1951) Sound scattering by solid cylinders and spheres. J Acoust Soc 23:405-418

Fulton RS (1984) Distribution and community structure of 
estuarine copepods. Estuaries 7:38-50

Geyer WR (1993) The importance of suppression of turbulence by stratification of the estuarine turbidity maximum. Estuaries 16:113-125

Grice GD, Hart AD (1962) The abundance, seasonal occurrence and distribution of epizooplankton between New York and Bermuda. Ecol Monogr 32:287-309

Haertel L, Osterberg C (1967) Ecology of zooplankton, benthos and fishes in the Columbia River estuary. Ecology 48: 459-472

Heinle DR, Flemer DA (1975) Carbon requirements of a population of the estuarine copepod Eurytemora affinis. Mar Biol 31:235-247

Heinle DR, Ustach JF, Flemer DA (1977) Detritus as food for estuarine copepods. Mar Biol 40:341-353

Herman S, Mihursky JA, McElean AJ (1968) Zooplankton and environmental characteristics of the Patuxent River Estuary 1963-1965. Chesapeake Sci 9:67-82

Holliday DV (1977) Extracting biophysical information from acoustic signatures of marine organisms. In: Andersen NR, Zahuranec BJ (eds) Ocean sound scattering prediction. Plenum Press, New York, p 619-624

Holliday DV, Pieper RE (1995) Bioacoustical oceanography at high frequencies. ICES J Mar Sci 52:279-296

Houde ED, Lovdal JA (1985) Patterns of variability in ichthyoplankton occurrences and abundance in Biscayne Bay, Florida. Estuar Coast Shelf Sci 20:79-104

Hough AR, Naylor E (1991) Field studies on retention of the planktonic copepod Eurytemora affinis in a mixed estuary. Mar Ecol Prog Ser 76:115-122

Jones KK, Simenstad CA, Higley DL, Bottom DL (1990) Community structure, distribution and standing stock of benthos, epibenthos and plankton in the Columbia River estuary. Prog Oceanogr 25:211-241

Kimmerer, WJ, Burau JR, Bennett WA (1998) Tidally oriented vertical migration and position maintenance of zooplankton in a temperate estuary. Limnol Oceanogr 43:1697-1709

Editorial responsibility: Kenneth Tenore (Contributing Editor), Solomons, Maryland, USA
Lawson CL, Hanson RJ (1974) Solving least squares problems. Prentice Hall, Englewood Cliffs, NJ

Morgan CA, Cordell JR, Simensted CA (1997) Sink or swim? Copepod population maintenance in the Columbia River estuarine turbidity-maxima region. Mar Biol 129:309-317

Napp JM, Ortner PB, Pieper RE, Holliday DV (1993) Biovolume-size spectra of epipelagic zooplankton using a Multifrequency Acoustic Profiling System (MAPS). Deep-Sea Res 40:445-459

Peitsch A (1995) Production rates of Eurytemora affinis in the Elbe estuary, comparison of field and enclosure production estimates. Hydrobiologia 311:127-137

Pieper RE, Holliday DV (1984) Acoustic measurements of zooplankton measurements in the sea. J Cons Int Explor Mer 41:226-238

Schubel JR (1968) Turbidity maximum of the Northern Chesapeake Bay. Science 161:1013-1015

Schubel JR, Biggs RB (1969) Distribution of Seston in Upper Chesapeake Bay. Chesapeake Sci 10:18-23

Setzler-Hamilton EM (1991) White perch. In: Funderburk SL, Mihursky JA, Jordan SJ, Riley D (eds) Habitat requirements for Chesapeake Bay living resources, 2nd edn. Living resources subcommittee, Chesapeake Bay Program, MD DNR, Annapolis, MD, p 12-1-12-20

Setzler-Hamilton EM, Hall L (1991) Striped bass. In: Funderburk SL, Mihursky JA, Jordan SJ, Riley D (eds) Habitat requirements for Chesapeake Bay living resources, 2nd edn. Living resources subcommittee, Chesapeake Bay Program, MD DNR, Annapolis, MD, p 13-1-13-31

Simensted CA, Morgan CA, Cordell JR, Baross JA (1994) Flux, passive retention and active residence of zooplankton in Columbia River estuarine turbidity maxima. In: Dyer KR, Orth RJ (eds) Changes in fluxes in estuaries. Olsen and Olsen, Fredensborg, p 473-482

White JR, Roman MR (1992) Seasonal study of grazing by metazoan zooplankton in the mesohaline Chesapeake Bay. Mar Ecol Prog Ser 76:251-261

Submitted: March 19, 1999; Accepted: July 13, 2000 Proofs received from author(s): March 8, 2001 